\title{
Effect of Dates of Planting on Growth, Yield and Quality of Menthol Mint (Mentha arvensis L.) Cultivars Planted During Rabi Season
}

\author{
Shwetha Desai $^{1 *}$, T.N. Pushpa ${ }^{1}$, D. Srikantaprasad ${ }^{1}$, V. Kantharaju ${ }^{2}$, \\ I.B. Biradar ${ }^{3}$, R.M. Shalini ${ }^{4}$ and M.R. Asha ${ }^{4}$
}

${ }^{1}$ Department of Plantation, Spices, Medicinal and Aromatic Crops, ${ }^{2}$ Department of Pathology and Head (AICRP Tropical Fruits), ${ }^{3}$ Department of Agronomy, K.R.C. College of Horticulture, Arabhavi - 591 218, University of Horticultural Sciences, Bagalkot - 587 102, Karnataka, India

*Corresponding author

\section{A B S T R A C T}

\section{Keywords}

Menthol mint, Dates of planting, Cultivar, Net returns, $\mathrm{B}$ : $\mathrm{C}$ ratio

Article Info

Accepted:

06 August 2018

Available Online:

10 September 2018
The field study was conducted to determine the effect of different dates of planting $\left(1^{\text {st }}\right.$ October, $1^{\text {st }}$ November and $1^{\text {st }}$ December) and different cultivars (Kosi, Kushal, Sambhav, Saksham and Himalaya) on growth, yield and quality of menthol mint planted during rabi 2017- 2018 in split design with three replications under Northern dry zone of Karnataka. The results revealed that growth parameters like plant height, spread and number of branches $(63.30,52.11 \mathrm{~cm}$ and 25.92 , respectively) and yield parameters like fresh and shade dried herbage yield (9.04 and $7.23 \mathrm{t} / \mathrm{ha})$, oil yield and content $(80.08 \mathrm{~kg} / \mathrm{ha}$ and 1.09 $\%)$ recorded maximum when crop planted on $1^{\text {st }}$ November irrespective of cultivars. Among different cultivars cv. Kushal was superior in terms of growth, yield and quality parameters, which recorded maximum plant spread and number of branches $(49.32 \mathrm{~cm}$ and 23.63), fresh and shade dried herbage yield (9.91 and $7.93 \mathrm{t} / \mathrm{ha})$ and oil yield (76.49 $\mathrm{kg} / \mathrm{ha})$, while cv. Saksham recorded maximum oil content $(1.04 \%)$ and menthol content $(71.65$ $\%$ ). The maximum net returns (₹ 81,158.00/ha) and B: C ratio (2.76) were obtained when cv. Kushal planted on $1^{\text {st }}$ November 2017-2018.

\section{Introduction}

Menthol mint or Japanese mint (Mentha arvensis L.), a member of Lamiaceae is a perennial herbaceous aromatic plant but cultivated as annual for natural menthol. It is a source of major raw material for the flavours and fragrance industry. The shade dried herb upon distillation yields mint oil, further processing (chilling) provides menthol crystals and de-mentholised mint oil. It is valuable commercially because of its high oil yield and the menthol content. India is a leading producer of this crop in world having 0.30 
million ha area with annual production of 38,000 metric tonnes of essential oil with average productivity of around 120 kilograms per hectare (Anon., 2015). In India, it is commercially grown in sub- tropical plains as a summer season crop after the harvest of winter season crops viz., potato, mustard and pea etc. Menthol mint is transplanted from mid-February to mid-April, depending upon the time of harvesting of preceding crop. Indian monsoon is very erratic and uncertain. Early onset of monsoon rains cause heavy losses in the productivity of menthol mint as pre monsoon rains adversely affect growth, yield and quality of oil. Since the research done on this crop in Karnataka itself is very meager, there is a need for development of package of practices for its large scale cultivation for betterment of the farming community in Northern dry zone of Karnataka. The canal irrigation facility was available from July to March in Gataprabha command area. Hence, to promote this crop there is need to standardize the best planting date along with suitable cultivar for menthol mint cultivation during rabi season.

\section{Materials and Methods}

The present investigation was carried out during 2017-2018 for rabi season in the Department of Plantation, Spices, Medicinal and Aromatic Crops, Kittur Rani Channamma College of Horticulture, Arabhavi, University of Horticultural Sciences, Bagalkot, Karnataka, India, situated in northern dry zone (Zone No. 3; Region-2) of Karnataka at $16^{\circ} 15^{\prime} \mathrm{N}$ latitude and $74^{\circ} 45^{\prime} \mathrm{E}$ longitude, at an altitude of $612 \mathrm{~m}$ above mean sea level.

\section{Climatic condition and soil characteristics of the experimental site}

The experimental site is considered to have the benefit of both south-west and north-east monsoons. During experiment, crop received about $121.80 \mathrm{~mm}$ rainfall (October 2017 April 2018), the mean temperature and mean relative humidity $(\mathrm{RH})$ ranged from $26.20^{\circ} \mathrm{C}$ and 88.70 per cent (October 2017) to $24.25^{\circ} \mathrm{C}$ and 68.80 per cent (April 2018), respectively. The soil of experimental site is sandy clay loam (vertisols) with alkaline $\mathrm{pH}$ (8.79).

\section{Experimental details}

The experiment was laid out in split-plot design with three replications, considering three planting dates $\left(1^{\text {st }}\right.$ October, $1^{\text {st }}$ November and $1^{\text {st }}$ December) as main treatments and five cultivars (Kosi, Kushal, Sambhav, Saksham and Himalaya) as sub treatments. The plants were uprooted and white stolons of uniform thickness were separated. They were cut into of 7.0 to $10.0 \mathrm{~cm}$ long cuttings having 2-3 nodes and dipped in 0.3 per cent COC for 5-10 minutes before planting. The furrows were opened at $45 \mathrm{~cm}$ interval in each plot. Prepared stolons were placed horizontally in mid of furrows at $30 \mathrm{~cm}$ spacing, at a depth of 2.5 to $4.0 \mathrm{~cm}$ and later covered with soil. Irrigation was given immediately after planting and subsequent irrigations were given at eight to ten days intervals depending on the rainfall and soil moisture. The crop was harvested at 150 days after planting.

Observations on growth parameters like plant height, plant spread, number of branches and yield parameters like fresh and shade dried herbage yield were recorded on five randomly selected plants in each replication of different treatments at harvest. The leaf area was calculated on five randomly selected plants by using Biovis instrument. For estimation of total dry matter accumulation the selected five plants were uprooted from soil and the different plant parts like leaves, stem and roots were separated and dried in oven for $15 \mathrm{hrs}$ at $60^{\circ} \mathrm{C}$. For estimation of oil yield known weight of fresh herbage from each plot was taken and withered for few hours in shade. 
The plant material was chopped into small pieces and essential oil extraction was done by hydro-steam distillation method using essential oil extraction unit of $10 \mathrm{~kg}$ capacity (CSIR - Institute of Himalayan Bioresource Technology patented technology). Essential oil content was estimated on shade dried weight basis and menthol content was estimated using gas chromatography and both are expressed in percentage $(\%)$.

The price of the inputs was considered for working out the economics of the various treatment combinations. Cost of cultivation was computed as per treatments. Net returns per hectare was calculated by deducting the cost of cultivation from gross income per hectare and benefit cost ratio (B: C) was worked out for different treatments. Fisher method of analysis of variance as given by Panse and Sukhatme (1967) was applied for analysis and interpretation of data. The level of significance used in ' $\mathrm{F}$ ' test was at $\mathrm{P}=0.05$ and critical difference (CD) values were worked out wherever ' $F$ ' test was significant.

\section{Results and Discussion}

\section{Growth parameters}

The growth parameters were significantly influenced by dates of planting at harvest. Planting on $1^{\text {st }}$ November 2017 recorded maximum plant height $(63.30 \mathrm{~cm})$, plant spread $(52.11 \mathrm{~cm})$ and number of branches (25.92) compared to crop planted on $1^{\text {st }}$ October 2017 which recorded minimum height $(47.27 \mathrm{~cm})$, plant spread $(38.15 \mathrm{~cm})$ and branches (16.40). The prolonged growing period coupled with congenial climatic conditions might have promoted luxuriant vegetative growth. Higher plant spread and numbers of branches under $1^{\text {st }}$ November 2017 were due to moderate temperature at the time of planting, which favoured better establishment and growth of shoots and root, thus plants could utilize above and underground resources more efficiently. The results are in line with the findings of Brar et al., (2014) in menthol mint, Kumar and Sood (2011) in pepper mint, Farooqi et al., (1990), Jayanthi et al., (2013) in davana, Solanki and Shaktawat (1999) and Jain et al., (2003) in isabgol, Singh et al., (2008) in geranium.

Different cultivars of menthol mint irrespective of planting dates recorded significantly different growth parameters at harvest. Among the different cultivars cv. Sambhav recorded maximum plant height $(56.72 \mathrm{~cm})$, while cv. Saksham recorded minimum plant height $(52.12 \mathrm{~cm})$. At same time, cv. Kushal recorded maximum plant spread $(49.32 \mathrm{~cm})$ and number of branches (23.63) compared to cv. Saksham which recorded minimum plant spread $(40.09 \mathrm{~cm})$ and number of branches (18.80). Increased growth attributes in cv. Kushal might be due to more plant population and better field establishment as it developed through tissue culture and its suitability to late planting between rabi and kharif season. Change in geographical location or inherent genetic variations could be the major reason for variation in growth parameters among different cultivars. The present results are in contrary to the findings of Nilofer et al., (2015), Lal (2013) where cv. Kosi was superior in terms of growth attributes (Table $1)$.

Interaction between dates of planting and cultivars had significant influence on growth parameters at harvest. The cv. Sambhav planted on $1^{\text {st }}$ November $2017 \quad\left(\mathrm{P}_{2} \mathrm{~V}_{3}\right)$ registered maximum plant height $(66.60 \mathrm{~cm})$ compared to cv. Saksham planted on $1^{\text {st }}$ October 2017 which recorded minimum plant height $(45.93 \mathrm{~cm})$ which might be attributed to synergistic effect of planting date and cultivar which contributed to highest plant height. Among the different interactions, cv. Kushal 
planted on $1^{\text {st }} \quad$ November $2017 \quad\left(\mathrm{P}_{2} \mathrm{~V}_{2}\right)$ registered maximum plant spread $(57.83 \mathrm{~cm})$ in both East-West and North-South directions and number of branches (29.53) compared to cv. Saksham planted on $1^{\text {st }}$ October 2017, which recorded minimum plant spread (32.70 $\mathrm{cm})$ in both East-West and North-South directions and number of branches (14.67). This might be attributed to combined effect of planting date and cultivar that resulted in increased plant spread there by more number of lateral buds leading to more number of branches. These results are in line with findings of Ram et al., (2000), Chauhan et al., (2011) and Sharma (2012) in menthol mint.

\section{Physiological parameters}

Physiological parameters varied significantly with dates of planting at harvest. Planting on $1^{\text {st }}$ November 2017 recorded maximum leaf area $\left(3913.15 \mathrm{~cm}^{2} /\right.$ plant $)$ and total dry matter accumulation (114.80 g/plant) compared to planting on $1^{\text {st }}$ October 2017 which recorded minimum leaf area $\left(2356.55 \mathrm{~cm}^{2} /\right.$ plant $)$ and total dry matter accumulation ( $91.25 \mathrm{~g} /$ plant $)$. This might be due to the plants grown under favorable weather conditions led to the length of the vegetative growth period and abundance represented by increasing the plant height, spread and number of branches resulted in increased leaf area which led to increase the efficiency of photosynthesis, which reflected significant increase in total dry matter accumulation. The results are in conformity with the findings of Brar et al., (2014) in menthol mint, Kumar and Sood (2011) in pepper mint, Farooqi et al., (1990), Jayanthi et al., (2013) in davana, Solanki and Shaktawat (1999) and Jain et al., (2003) in isabgol, Singh et al., (2008) in geranium.

Leaf area and total dry matter accumulation were significantly varied with different cultivars. At harvest, among the different cultivars, cv. Kushal recorded maximum leaf area $\left(3810.37 \mathrm{~cm}^{2} /\right.$ plant $)$ and total dry matter accumulation (122.50 g/plant) compared to cv. Saksham which recorded minimum leaf area (2415.58 $\mathrm{cm}^{2} /$ plant) and total dry matter accumulation (82.59 g/plant). The maximum physiological parameters in cv. Kushal might be attributed to increased number of branches and more plant spread. However variation in physiological parameters might be due to the varietal characteristics and response of trait to environmental condition. The present results are in contrary to the findings of Nilofer et al., (2015), Lal (2013) where cv. Kosi was superior in terms of growth attributes. Physiological parameter like leaf area varied significantly with the interaction of dates of planting and cultivars whereas total dry matter accumulation found non-significant at harvest. Among the different interactions, cv. Kushal planted on $1^{\text {st }}$ November $2017 \quad\left(\mathrm{P}_{2} \mathrm{~V}_{2}\right)$ registered maximum leaf area (4588.86 $\mathrm{cm}^{2} /$ plant) compared to $\mathrm{cv}$. Saksham planted on $1^{\text {st }}$ October 2017 which recorded minimum leaf area $\left(1612.31 \mathrm{~cm}^{2} /\right.$ plant). This might be attributed to combined effect of planting date and cultivar that resulted in increased plant spread there by more number of lateral buds leading to more number of branches. Higher leaf area might be due congenial weather conditions during that period which could be attributed to the increased growth expressed by increased number of branches and more plant spread and also due to favourable influence of planting date and cultivars which resulted in maximum leaf area (Table 2).

\section{Yield and quality parameters}

Menthol mint planted on $1^{\text {st }}$ November 2017 $\left(\mathrm{P}_{1}\right)$ was significantly superior in terms of fresh herbage yield (9.04 t/ha), shade dried herbage yield $(7.23 \mathrm{t} / \mathrm{ha})$, oil yield (80.08 $\mathrm{kg} / \mathrm{ha}$ ) and oil content (1.09), while minimum fresh herbage yield (6.09 t/ha), shade dried herbage yield (4.87 t/ha), oil yield (38.61 $\mathrm{kg} / \mathrm{ha}$ ) and oil content $(0.75)$ were recorded by planting on $1^{\text {st }}$ October 2017 (Table 3). 
Table.1 Effect of dates of planting on growth parameters of menthol mint (Mentha arvensis L.) cultivars at harvest (150 DAP)

\begin{tabular}{|c|c|c|c|c|c|c|c|c|c|c|c|c|c|c|c|c|c|c|}
\hline \multicolumn{19}{|c|}{ Growth parameters } \\
\hline \multirow[t]{2}{*}{ Treatments } & \multicolumn{6}{|c|}{ Plant height (cm) } & \multicolumn{6}{|c|}{ Plant spread (E-W and N-S) (cm) } & \multicolumn{6}{|c|}{ Number of branches } \\
\hline & $\mathbf{V}_{1}$ & $\mathbf{V}_{2}$ & $\mathbf{V}_{3}$ & $\mathbf{V}_{4}$ & $\mathbf{V}_{5}$ & Mean & $\mathbf{V}_{1}$ & $\mathbf{V}_{2}$ & $\mathbf{V}_{3}$ & $\mathbf{V}_{4}$ & $\mathbf{V}_{5}$ & Mean & $\mathbf{V}_{1}$ & $\mathbf{V}_{2}$ & $\mathbf{V}_{3}$ & $\mathbf{V}_{4}$ & $\mathbf{V}_{5}$ & Mean \\
\hline $\mathbf{P}_{1}$ & 47.20 & 47.53 & 49.03 & 45.93 & 46.70 & 47.27 & 36.93 & 42.38 & 39.92 & 32.70 & 38.83 & 38.15 & 16.23 & 18.03 & 16.47 & 14.67 & 16.60 & 16.40 \\
\hline $\mathbf{P}_{2}$ & 63.17 & 65.87 & 66.60 & 58.57 & 62.30 & 63.30 & 49.90 & 57.83 & 55.27 & 47.07 & 50.50 & 52.11 & 24.03 & 29.53 & 27.47 & 22.67 & 25.93 & 25.92 \\
\hline $\mathbf{P}_{3}$ & 52.73 & 54.13 & 54.53 & 51.87 & 54.43 & 53.53 & 44.83 & 47.77 & 47.03 & 40.50 & 45.97 & 45.22 & 19.73 & 23.33 & 22.30 & 19.07 & 21.67 & 21.22 \\
\hline Mean & 54.36 & 55.84 & 56.72 & 52.12 & 54.47 & & 43.88 & 49.32 & 47.40 & 40.09 & 45.10 & & 19.99 & 23.63 & 22.08 & 18.80 & 21.40 & \\
\hline \multicolumn{19}{|c|}{ For comparison of mean } \\
\hline & & & \multicolumn{2}{|c|}{ S.Em \pm} & \multicolumn{2}{|c|}{ CD@ $5 \%$} & \multicolumn{3}{|c|}{ S.Em \pm} & \multicolumn{3}{|c|}{ CD@ $5 \%$} & \multicolumn{3}{|c|}{ S.Em \pm} & \multicolumn{3}{|c|}{ CD@ $5 \%$} \\
\hline \multicolumn{3}{|c|}{ Planting dates(P) } & \multicolumn{2}{|c|}{0.64} & \multicolumn{2}{|c|}{2.50} & \multicolumn{3}{|c|}{0.74} & \multicolumn{3}{|c|}{2.89} & \multicolumn{3}{|c|}{0.14} & \multicolumn{3}{|c|}{0.56} \\
\hline \multicolumn{3}{|c|}{ Varieties (V) } & \multicolumn{2}{|c|}{0.46} & \multicolumn{2}{|c|}{1.33} & \multicolumn{3}{|c|}{0.45} & \multicolumn{3}{|c|}{1.31} & \multicolumn{3}{|c|}{0.33} & \multicolumn{3}{|c|}{0.95} \\
\hline \multicolumn{3}{|c|}{$\mathbf{V}$ at same level of $\mathbf{P}$} & \multicolumn{2}{|c|}{0.79} & \multicolumn{2}{|c|}{2.31} & \multicolumn{3}{|c|}{0.78} & \multicolumn{3}{|c|}{2.27} & \multicolumn{3}{|c|}{0.57} & \multicolumn{3}{|c|}{1.65} \\
\hline $\begin{array}{l}\text { P at same or c } \\
\text { V }\end{array}$ & fferent & evel of & & & & 03 & & 5.06 & & & 17.47 & & & 2.63 & & & 7.87 & \\
\hline $\begin{array}{l}\text { Main plot } \\
\mathrm{P}_{1}: 1^{\text {st }} \text { Oct } \\
\text { DAP: Day }\end{array}$ & $\begin{array}{l}\text { treatme } \\
\text { ber } \mathrm{P}_{2} \text { : } \\
\text { after pl }\end{array}$ & $\begin{array}{l}\text { ts }(\mathbf{P}) \\
\text { t Nover } \\
\text { nting }\end{array}$ & ber $\mathrm{P}_{3}$ : & ${ }^{\text {st }}$ Dece & iber & & & & $\begin{array}{l}\text { Sub pl } \\
\mathrm{V}_{1}: \mathrm{Ko}\end{array}$ & $\begin{array}{l}\text { t treatr } \\
, \mathrm{V}_{2}: \mathrm{K}\end{array}$ & $\begin{array}{l}\text { ents }(\mathbf{V}) \\
\text { shal, } V_{3}\end{array}$ & Sambh & $, \mathrm{V}_{4}: \mathrm{S}$ & ksham a & $\mathrm{d} \mathrm{V}_{5}: \mathrm{H}$ & malaya & & \\
\hline
\end{tabular}

Table.2 Effect of dates of planting on physiological parameters of menthol mint (Mentha arvensis L.) cultivars at harvest (150 DAP)

\begin{tabular}{|c|c|c|c|c|c|c|c|c|c|c|c|c|}
\hline \multirow[t]{2}{*}{ Treatments } & \multicolumn{6}{|c|}{ Leaf area (cm²/plant) } & \multicolumn{6}{|c|}{ Total dry matter accumulation (g/plant) } \\
\hline & $\mathbf{V}_{1}$ & $\mathbf{V}_{2}$ & $\mathbf{V}_{3}$ & $\mathbf{V}_{4}$ & $\mathbf{V}_{5}$ & Mean & $\mathbf{V}_{1}$ & $\mathbf{V}_{2}$ & $\mathbf{V}_{3}$ & $\mathbf{V}_{4}$ & $\mathbf{V}_{5}$ & Mean \\
\hline $\mathbf{P}_{1}$ & 2006.27 & 3259.38 & 2805.36 & 1612.31 & 2099.45 & 2356.55 & 75.33 & 118.97 & 105.83 & 71.12 & 85.00 & 91.25 \\
\hline $\mathbf{P}_{2}$ & 3782.03 & 4588.86 & 4034.24 & 3176.9 & 3983.73 & 3913.15 & 110.93 & 134.60 & 118.37 & 93.23 & 116.87 & 114.80 \\
\hline $\mathbf{P}_{\mathbf{3}}$ & 2649.77 & 3582.88 & 3437.69 & 2457.55 & 3179.53 & 3061.48 & 86.60 & 113.93 & 109.48 & 83.43 & 102.03 & 99.09 \\
\hline Mean & 2812.69 & 3810.37 & 3425.76 & 2415.58 & 3087.57 & & 90.95 & 122.50 & 111.22 & 82.59 & 101.30 & \\
\hline \multicolumn{13}{|c|}{ For comparison of mean } \\
\hline & & & \multicolumn{2}{|c|}{ S.Em \pm} & \multicolumn{2}{|c|}{ CD@5\% } & \multicolumn{3}{|c|}{ S.Em \pm} & \multicolumn{3}{|c|}{ CD@ $5 \%$} \\
\hline \multicolumn{3}{|c|}{ Planting dates(P) } & \multicolumn{2}{|c|}{64.82} & \multicolumn{2}{|c|}{254.52} & \multicolumn{3}{|c|}{2.38} & \multicolumn{3}{|c|}{9.34} \\
\hline \multicolumn{3}{|c|}{ Varieties (V) } & \multicolumn{2}{|c|}{68.09} & \multicolumn{2}{|c|}{198.73} & \multicolumn{3}{|c|}{2.26} & \multicolumn{3}{|c|}{6.60} \\
\hline \multicolumn{3}{|c|}{$V$ at same level of $P$} & \multicolumn{2}{|c|}{117.93} & \multicolumn{2}{|c|}{344.22} & \multicolumn{3}{|c|}{3.92} & \multicolumn{3}{|c|}{ NS } \\
\hline \multicolumn{3}{|c|}{ P at same or different level of $\mathbf{V}$} & \multicolumn{2}{|c|}{619.03} & \multicolumn{2}{|c|}{1977.81} & \multicolumn{3}{|c|}{21.17} & \multicolumn{3}{|c|}{ NS } \\
\hline
\end{tabular}

Main plot treatments $(\mathbf{P})$

$\mathrm{P}_{1}: 1^{\text {st }}$ October $\mathrm{P}_{2}: 1^{\text {st }}$ November $\mathrm{P}_{3}: 1^{\text {st }}$ December

DAP: Days after planting
Sub plot treatments $(\mathrm{V})$

$\mathrm{V}_{1}$ : Kosi, $\mathrm{V}_{2}:$ Kushal, $\mathrm{V}_{3}$ : Sambhav, $\mathrm{V}_{4}$ : Saksham and $\mathrm{V}_{5}$ : Himalaya 
Table.3 Effect of dates of planting on yield parameters of menthol mint (Mentha arvensis L.) cultivars at harvest (150 DAP)

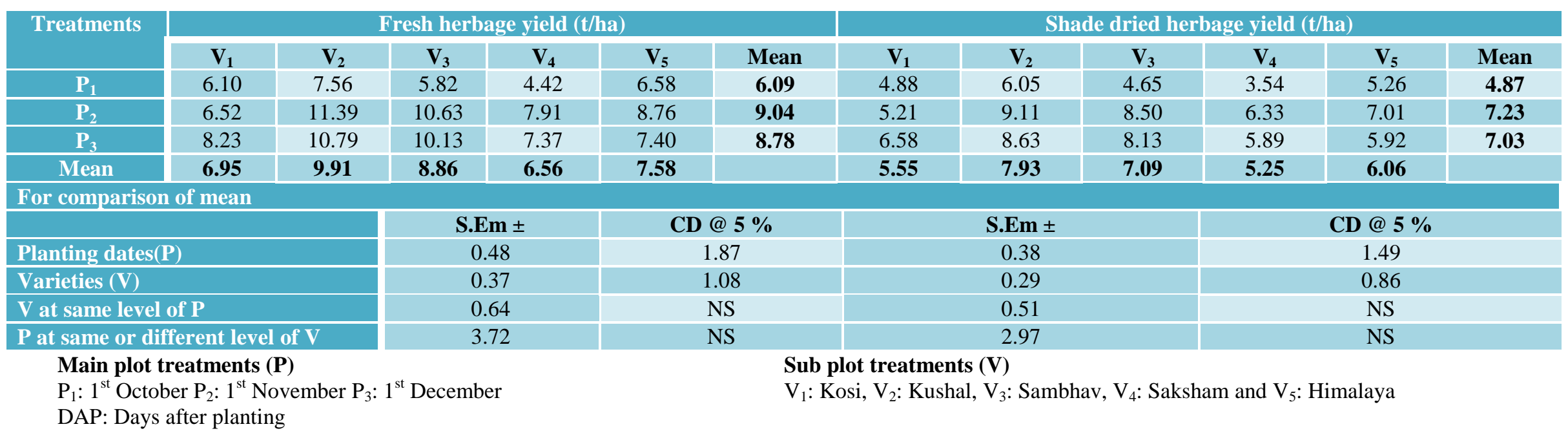

Table.4 Effect of dates of planting on oil content, oil yield and menthol content of menthol mint (Mentha arvensis L.) cultivars at harvest (150 DAP)

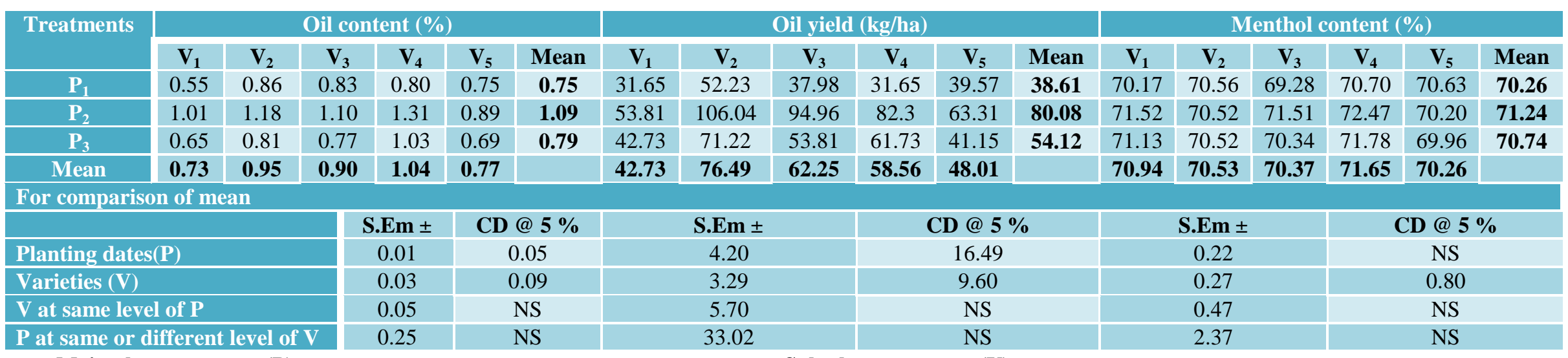

\section{Main plot treatments $(\mathbf{P})$}

$\mathrm{P}_{1}: 1^{\text {st }}$ October $\mathrm{P}_{2}: 1^{\text {st }}$ November $\mathrm{P}_{3}: 1^{\text {st }}$ December

DAP: Days after planting

\section{Sub plot treatments $(\mathrm{V})$}

$\mathrm{V}_{1}$ : Kosi, $\mathrm{V}_{2}$ : Kushal, $\mathrm{V}_{3}$ : Sambhav, $\mathrm{V}_{4}$ : Saksham and $\mathrm{V}_{5}$ : Himalaya 
Table.5 Economics of cultivation as influenced by interaction of dates of planting and cultivars of menthol mint (Mentha arvensis L.)

\begin{tabular}{|c|c|c|c|c|}
\hline Treatments & $\begin{array}{c}\text { Cost of } \\
\text { cultivation } \\
\text { (₹/ha) }\end{array}$ & $\begin{array}{c}\text { Gross returns } \\
(\mathcal{F} / \mathbf{h a})\end{array}$ & $\begin{array}{c}\text { Net returns } \\
(\mathcal{F} / \mathrm{ha})\end{array}$ & B: C Ratio \\
\hline $\mathbf{P}_{\mathbf{1}} \mathbf{V}_{\mathbf{1}}$ & $40,800.00$ & $37,980.00$ & $-2,820.00$ & 0.93 \\
\hline $\mathbf{P}_{\mathbf{1}} \mathbf{V}_{2}$ & $42,260.00$ & $62,676.00$ & $20,416.00$ & 1.48 \\
\hline $\mathbf{P}_{\mathbf{1}} \mathbf{V}_{\mathbf{3}}$ & $40,520.00$ & $45,576.00$ & $5,056.00$ & 1.12 \\
\hline $\mathbf{P}_{\mathbf{1}} \mathbf{V}_{4}$ & $39,120.00$ & $37,980.00$ & $-1,140.00$ & 0.97 \\
\hline $\mathbf{P}_{\mathbf{1}} \mathbf{V}_{5}$ & $41,280.00$ & $47,484.00$ & $6,204.00$ & 1.15 \\
\hline $\mathbf{P}_{2} \mathbf{V}_{1}$ & $41,220.00$ & $64,572.00$ & $23,352.00$ & 1.56 \\
\hline $\mathbf{P}_{2} \mathbf{V}_{2}$ & $46,090.00$ & $1,27,248.00$ & $81,158.00$ & 2.76 \\
\hline $\mathbf{P}_{2} \mathbf{V}_{3}$ & $45,330.00$ & $1,13,952.00$ & $68,622.00$ & 2.51 \\
\hline $\mathbf{P}_{2} \mathbf{V}_{4}$ & $42,610.00$ & $98,760.00$ & $56,150.00$ & 2.31 \\
\hline $\mathbf{P}_{2} \mathbf{V}_{5}$ & $43,460.00$ & $75,972.00$ & $32,512.00$ & 1.74 \\
\hline $\mathbf{P}_{3} \mathbf{V}_{1}$ & $42,930.00$ & $51,276.00$ & $8,346.00$ & 1.19 \\
\hline $\mathbf{P}_{3} \mathbf{V}_{2}$ & $45,490.00$ & $85,464.00$ & $39,974.00$ & 1.87 \\
\hline $\mathbf{P}_{3} \mathbf{V}_{3}$ & $44,830.00$ & $64,572.00$ & $19,742.00$ & 1.44 \\
\hline $\mathbf{P}_{3} \mathbf{V}_{4}$ & $42,070.00$ & $74,076.00$ & $32,006.00$ & 1.76 \\
\hline $\mathbf{P}_{3} \mathbf{V}_{5}$ & $42,100.00$ & $49,380.00$ & $7,280.00$ & 1.17 \\
\hline
\end{tabular}

Main plot treatments (P)

$\mathrm{P}_{1}: 1^{\text {st }}$ October

$\mathrm{P}_{2}: 1^{\text {st }}$ November

$\mathrm{P}_{3}: 1^{\text {st }}$ December

DAP: Days after planting

This might be due to increased plant growth in terms of plant height, spread, branches, leaf area and total dry matter accumulation resulting in higher fresh, shade dried herb, oil yield and oil content. These findings are in agreement to those reported by Brar et al., (2014) in menthol mint, Singh et al., 2003 in bergamot mint, Mann and Vyas., 2001 and Chandra et al., (2006) in isabgol, Zoimbra and Sas-Golak (2002) in basil, Kumar and Sood (2011) in pepper mint, Jayanthi et al., (2013) in davana. The influence of planting dates was found non-significant with respect to menthol content (Table 4).

Different cultivars of menthol mint irrespective of planting dates recorded significantly different yield parameters at harvest. cv. Kushal recorded maximum fresh herb yield (9.91 t/ha), shade dried herbage yield $(7.93 \mathrm{t} / \mathrm{ha})$ and oil yield $(76.49 \mathrm{~kg} / \mathrm{ha})$ compared to cv. Saksham which recorded minimum fresh herb yield (6.56 t/ha), shade dried herbage yield $(5.25 \mathrm{t} / \mathrm{ha})$, but cv. Kosi recorded minimum oil yield $(42.73 \mathrm{~kg} / \mathrm{ha})$. cv. Saksham recorded maximum oil content (1.04 $\%)$ and menthol content $(71.65 \%)$. The possible reason for the increase in fresh herb yield could be due to higher growth attributes viz., plant height, plant spread and number of branches and increased physiological parameters there by increased yield and quality parameters. However findings of the study are supported by the idea that the yield 
is highly variable factor depending upon cultivar, climatic conditions, incidence of pest and diseases. The present results are in contrary to the findings of Kumar et al., (2000), Chauhan et al., (2011), Lal (2013) and Nilofer et al., (2015), where cv. Kosi was superior in terms of yield and quality attributes.

The effect of interaction between cultivars and planting date found non-significant on yield and quality parameters.

\section{Economics}

The maximum cost of cultivation (₹ 46,090.00/ha), gross returns (₹ 1,27,248.00/ha), net returns ( $₹ 81,158.00 /$ ha) and $\mathrm{B}$ : C ratio (2.76) were obtained when cv. Kushal planted on $1^{\text {st }}$ November 2017, while minimum cost of cultivation ( $₹ 39,120.00 /$ ha) and gross returns (₹ 37,980.00/ha) were recorded when cv. Saksham planted on $1^{\text {st }}$ October 2017. But minimum B: C ratio was obtained when cv. Kosi planted on $1^{\text {st }}$ October 2017 (0.93). This was because of the highest production of herbage yield which resulted in increased essential oil yield leads to maximum net returns and B: $\mathrm{C}$ ratio. Similar results were also reported by Nilofer (2015) in menthol mint (Table 5).

During rabi season, planting of menthol mint cv. Kushal on $1^{\text {st }}$ November is advisable to obtain maximum herbage, oil yield, net returns and $\mathrm{B}$ : $\mathrm{C}$ ratio under northern dry zone of Karnataka.

\section{References}

Anonymous, 2015, Current data and market activity. Multi Commodity Exchange Limited.

Brar, S. K., Gill, B. S., Brar, A. S. and Kaur, T., 2014, Straw mulch effect on biomass yield, oil yield and oil quality of Japanese mint (Mentha arvensis L.) harvested at successive intervals. J. Essential Oil Res. 17(4): 676-695.

Chandra, R., Kumar, D., Jha B. K., Gajbhiye N. A. and Aishwath O. P., 2006, Influence of sowing time on growth and yield of Plantago ovata Forsk. under middle Gujarat conditions. Indian J. Horti., 63(4): 424-427.

Chauhan, R. K., Anwar, M., Chand, S. and Patra, D. D., 2011, Influence of different dates of planting on growth, herb, oil yield and quality of essential oil of Menthol mint (Mentha arvensis) in North Indian Plain. Arch. Agron \& Soil Sci. 58(2): 223-232.

Farooqi, A. A., Devaiah, K. A., Vasundhara, M. and Dasharathrao, N. D., 1990, Influence of planting season and plant density on growth and yield of essential oil in davana. Indian Perfumer. 34(4): 274-277.

Jain, K. K., Singh, P. and Sharma, S. K., 2003, Response of isabgol (Plantago ovata Forsk.) to sowing time and nitrogen. J. Maharastra Agric. Sci. 28(3): 322-323.

Jayanthi, M., Vijayakumar, A., Vananagamudi, K. and Rajamani, K., 2013, Influence of date of planting on growth and yield attributes and resultant seed quality of davana. American J. Plant Sci. 4: 1721-1724.

Kumar, A. V. and Sood, M., 2011, Effect of transplanting time, spacing and fertilizers on herbage and oil yield of Mentha piperita L. Int. J. farm Sci. 1(2): 68-74.

Kumar, S., Bahl, J. R., Bansal, R. P., Kukreja, A. K., Garg, S. N., Naqvi, A. A., Luthra, R. and Sharma, S., 2000, Profiles of the essential oils of Indian menthol mint Mentha arvensis cultivars at different stages of crop growth in northern plains. J. Med. Arom. Plant Sci. 22(1): 774-786. 
Lal, R. K., 2013, Adaptability patterns and stable cultivar selection in menthol mint (Mentha arvensis L.). Ind. Crops and Prod. 50: 176-181.

Mann, P. S and Vyas, A. K., 2001, Effect of sowing dates and nitrogen levels on yield, quality and net returns of blonde psyllium (Plantago ovata forsk.). Annal Agric Res., New Series. 22(3): 425-428.

Nilofer, Singh, S., Singh, K. A., Singh, H. N. and Kalra, A., 2015, Effect of weather conditions on growth, yield and quality of Menthol mint (Mentha arvensis L.) cultivars transplanted in different years on different dates under sub-tropical climate of North India. Indian J. Agric. Res. 6(2): 82-88.

Panse, V. G., and Sukhatme, P. V., 1967, Statistical Methods for Agricultural Workers, ICAR, New Delhi. Pp. 152174.

Ram, M., Ram, D., Singh, S., Roy, S. K. and Kumar, S., 2000, Effect of planting time on the growth and essential oil yield in different varieties of menthol mint (Mentha arvensis L.). J. Med. Arom. Plant Sci. 22(4): 400-403.
Sharma, S., 2012, Effect of dates of transplanting on the growth and oil yield of menthol mint (Mentha arvensis L.). Scholarly J. Agric. Sci. 2(7): 130132.

Singh, M., Singh, S. and Yaseen M., 2008, Standardization of planting time for optimum growth and oil production of geranium (Pelargonium graveolens L.) under North Indian plains. J. Spices and Arom. Crops. 17(3): 247-250.

Singh, M., Singh, V. P. and Saini, P., 2003, Optimum planting time and row spacing for bergamot mint (Mentha citrata) var. Kiran under sub-tropical plains of Central Uttar Pradesh. J. Spices and Arom. Crops. 12(2): 135-138.

Solanki, N. S. and Shaktawat, R. R. S., 1999, Effect of date of sowing and nitrogen on growth and yield of isabgol (Plantago ovata Forsk.). Indian J. Agric. Sci. 69(7): 528-529.

Zoimbra, M. and Sas-Golak, I., 2002. The influence of the date of planting on the yield and content of essential oil in the herb of three cultivars of aromatic basil. Herba polonica. 48(4): 295-299.

\section{How to cite this article:}

Shwetha Desai, T.N. Pushpa, D. Srikantaprasad, V. Kantharaju, I.B. Biradar, R.M. Shalini and Asha, M.R. 2018. Effect of Dates of Planting on Growth, Yield and Quality of Menthol Mint (Mentha arvensis L.) Cultivars Planted During Rabi Season. Int.J.Curr.Microbiol.App.Sci. 7(09): 625-633. doi: https://doi.org/10.20546/ijcmas.2018.709.074 